\title{
New records of rare males of Cryptocandona vavrai Kaufmann, 1900 (Crustacea, Ostracoda), with further additions to the description of the species
}

\author{
T. Namiotko ${ }^{*}$, P. Marmonier ${ }^{2}$, D.L. Danielopol ${ }^{3}$, D.J. Horne ${ }^{4}$, M. Artheau ${ }^{5}$ \\ ${ }^{1}$ University of Gdańsk, Institute of Biology, Department of Genetics and Cytology, Kładki 24, 80-822 Gdańsk, Poland \\ 2 Université de Rennes 1, UMR-CNRS 6553-Ecobio, Campus de Beaulieu, Bâtiment 14A, 263 Avenue du Général Leclerc, CS 74205, F-35042 \\ Rennes Cedex, France \\ 3 Austrian Academy of Sciences, Institute of Limnology, Mondseestrasse 9, A-5310 Mondsee, Austria \\ ${ }^{4}$ Queen Mary, University of London, Department of Geography, Mile End Road, London E1 4NS, UK \\ 5 Université Toulouse 3, Laboratoire Dynamique de la Biodiversité, UMR 5172, Bat 4R3, 118 Route de Narbonne, F-31062 Toulouse Cedex 9, \\ France
}

\begin{abstract}
Three males of Cryptocandona vavrai were discovered in geographically distant sites (UK, France, Romania), representing different environments (surface and underground waters). The species may be considered a parthenogen with rare occurrence of single males, the morphology of which was hitherto poorly known. The first complete description of males is given, which, together with comparative descriptions of females from surface waters at the UK site and underground waters at an additional site in eastern France, as well as consideration of the shape and size of the last juvenile stages, permits the presentation of a more complete description and an amended diagnosis of the species. Cryptocandona vavrai takes an intermediate position in the genus, lodged between stygobitic species and the cluster of more primitive $C$. reducta and $C$. brehmi. Due to a number of traits (broad calcified inner lamella of the valves, 3rd ramus podomere of the antennule lacking the posterior seta, hook-like shortest terminal seta of the cleaning leg, specific morphology of the male prehensile palps and hemipenis lobes) C. vavrai is fairly easily recognised, although there seems to be considerable intraspecific variation. The comparison between females from surface and underground waters revealed substantial elongation of the apical antennal claws, aesthetascs and the distal claw of the walking leg in the latter population. The major difference recorded among the compared males is the underdevelopment of the external claw $z_{2}$ on the 3rd endopodial podomere of the antenna in the male from the underground waters in Romania. The revealed variation could indicate that some populations may deserve a separate (sub-specific) taxonomic status. Finally, available data on the distribution and ecology of this species are summarised.
\end{abstract}

Keywords : Candoninae, groundwater, morphology, intraspecific variation, rare males.

\section{Introduction}

Cryptocandona vavrai was originally described by Kaufmann (1900a, 1900b) on the basis of female specimens collected from a bog near Gentilino in Switzerland (Canton Ticino). After several subsequent European records (Fig. 1), C. vavrai nowadays is considered the most common species of the genus and it is represented essentially by parthenogenetic populations;

\footnotetext{
* Corresponding author :

E-mail: namiotko@biotech.univ.gda.pl
}

males are only sporadically reported and always in small numbers only (Meisch 2000). The first single male of $C$. vavrai collected in summer from a gradually percolating outflow of a spring at Moxa in eastern Thuringia, Germany (Fig. 1) was reported by Klie (1938). He briefly described the carapace and illustrated the left clasping organ and the hemipenis. Subsequently, Husmann (1956) mentioned three males of $C$. vavrai found in the hyporheal of the Leine River near Burgstemmen, NE of Elze in Lower Saxonia, Germany (Fig. 1), but he did not offer any illustrations of these specimens. Finally, Eichhorn (1968) provided an extended description of males collected from a bog at 
Weiswampach in Luxembourg (Fig. 1). However, some of his illustrations were inaccurate and the description left a number of uncertainties with regard to various aspects of the limb morphology. In particular, the chaetotaxy of the antennule and antenna as well as details of the internal anatomy of the hemipenis remained insufficiently known. This was unfortunate as the male genital morphology in the genus Cryptocandona offers better characteristics than that of the female on which to define taxonomic position of the species. Only one more record of one male from Luxembourg (leg. R. Gerecke and I. Schrankel, det. Claude Meisch, unpublished) was briefly mentioned by Namiotko et al. (2001). Finally, one more finding of males identified as C. vavrai by Altinsaçli (1997) in NW Turkey ought to be mentioned here but actually, these specimens belong to a different species (see discussion below).

There were no further descriptions or records of males of C. vavrai until 1991, when one of us (D.J.H.) collected one male amongst of several females and juveniles from a marshy area at Gummer's How in the English Lake District (Fig. 1). This specimen allows us to present herein for the first time a complete description of a male of $C$. vavrai and amend the deficiencies mentioned above. More recently, one more decalcified male collected by one of us (M.A.) in 2003 from the hyporheic zone of a small river at Ille-sur-Têt, France (Fig. 1) became available to supplement our knowledge of the variability of the soft part morphology and the distribution of the $C$. vavrai males. One further dissected male specimen has been discovered in a collection of one of us (D.L.D.) originally made in 1968 while extensively sampling ground waters in the surroundings of Slănic-Moldova, Romania (Fig. 1). Both, the appendages and the valves of this specimen were mounted in glycerine on a slide labelled "Cryptocandona sp. $0^{\text {T". }}$. Although no hemipenes were found and the valves had unfortunately become decalcified, we have assumed this individual to be a male of $C$. vavrai since its clasping organs, as well as the chaetotaxy of the first antenna and the cleaning leg conformed to those of the specimen from the Gummer's How, thus facilitating further extension of our knowledge of the male morphology of the species. Apart from a description of the male from Gummer's How and the comparison with both other males available, a description of the females from Gummer's How is also presented in this paper, constituting further additions to the description of the species. A comparison of these females with those from an additional collection of one of us (P.M.) made in Arcine (France) contributed finally to the co- verage of this project. The material from the last mentioned collection was selected for inclusion in this paper since the collection site is reasonably close (c. 260 $\mathrm{km})$ to the type locality of the species.

The present paper continues a series of contributions to the revision of the taxonomy, ecology, distribution and phylogeny of the genus Cryptocandona Kaufmann, 1900 (Baltanás et al. 2000, Namiotko \& Danielopol 2001, Namiotko et al. 2001, Namiotko \& Danielopol 2002, Namiotko et al. 2005).

\section{Material and methods}

Figure 1 summarises the recent distribution of Cryptocandona vavrai based on the data entered in the NODE (Non-Marine Ostracod Distribution in Europe) database (Horne et al. 1998) ; localities numbered 1-4 correspond to those detailed below that formed the basis of the present contribution.

The material on which this contribution is based includes four main collections :

1. Gummer's How (GH), a hill (altitude $321 \mathrm{~m}$ a.s.1.) on the E side of the southern end of Windermere lake, Cumbria, UK (approx. geographical coordinates : $54^{\circ}$ 17 ' 00 " N, $2^{\circ} 56^{\prime} 00$ " W). The material (1 0', 25 우우, 9 juv.) was collected with a hand net by D.J.H. on 21 of August 1991 from marshy ground and ditches with slow-flowing water, altitude $200 \mathrm{~m}$ a.s.1., beside a

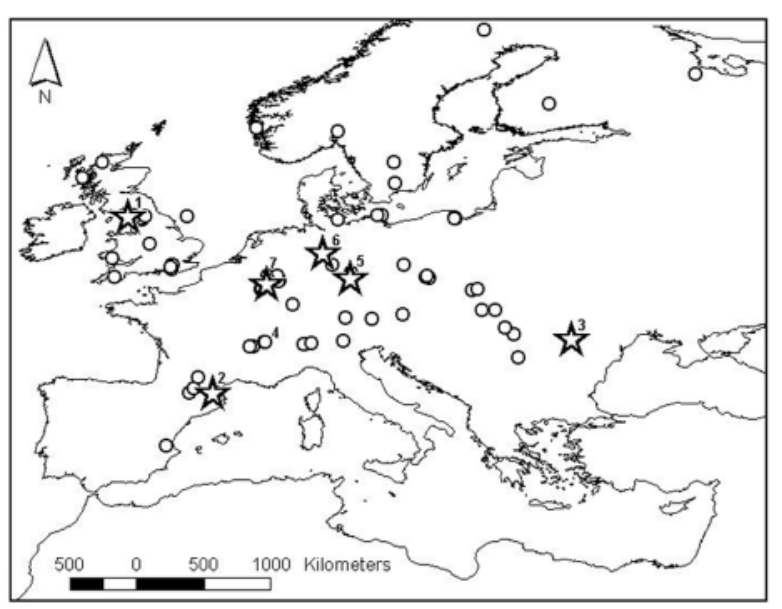

Fig. 1. Distribution of Cryptocandona vavrai in Europe (based on the NODE database, with supplementary records ; see text for details). Records with males indicated with a star, all other records as circles. Localities from which material was obtained for the present study numbered as follows : 1, Gummer's How ; 2, Illesur-Têt ; 3, Slănic-Moldova ; 4, Arcine. Other male records are numbered : 5, Moxa ; 6, Burgstemmen ; 7, Weiswampach and another locality in Luxembourg. 
small stream which drains from the S slope of Gummer's How into Windermere lake. The site was previously sampled on 16 of September 1987 (Horne 1988), when a pH of 6.8 was recorded and the following ostracods were obtained : Candona candida (O.F. Müller), Cryptocandona reducta (Alm), Cryptocandona vavrai Kaufmann, Cyclocypris ovum (Jurine), Eucypris pigra (Fischer) and Psychrodromus robertsoni (Brady \& Norman).

2. Ille-sur-Têt (IT), ca. 17 km W of Perpignan, Pyrénées-Orientales, Languedoc-Roussillon, France (geographical coordinates : $42^{\circ} 40^{\prime} 47^{\prime \prime} \mathrm{N}, 2^{\circ} 377^{\prime} 40^{\prime \prime} \mathrm{E}$; altitude : $170 \mathrm{~m}$ a.s.1.). The material (1 $\mathrm{o}^{7}, 2$ 우) was collected using a Bou-Rouch pump by M.A. on 13 of January 2003 from the hyporheic zone, $5 \mathrm{~m}$ away from the bank of the Têt River, downstream of the Ille-surTêt village, in the upper part of the Têt River alluvial floodplain. Physical and chemical variables of the water were as follows : temperature $=4^{\circ} \mathrm{C}$, oxygen concentration $=10.15 \mathrm{mg} \mathrm{dm}^{-3}$, phosphates content $=$ $0.11 \mathrm{mg} \mathrm{dm}^{-3}$, nitrates content $=0.9 \mathrm{mg} \mathrm{dm}^{-3}$, conductivity $=98 \mu \mathrm{S} \mathrm{cm}^{-1}$, total hardness $=44 \mathrm{mg} \mathrm{dm}^{-3}$ (as $\mathrm{CaCO}_{3}$ ). The site was coded as ROU082/T2 in the PASCALIS research project supported by the European Commission.

3. Slănic-Moldova (SM), 20 km S of Comănesti, Bacau county, Romania (approx. geographical coordinates : $46^{\circ} 12^{\prime} 00^{\prime \prime} \mathrm{N}, 26^{\circ} 26^{\prime} 00^{\prime \prime} \mathrm{E}$; altitude : $700 \mathrm{~m}$ a.s.1.). The material $\left(10^{7}\right)$ was collected using a Cvetkov net by D.L.D. accompanied by E. Serban on 8 of October 1968 from a well at the farm of Oprea Sližan.

4. Arcine (AR), $25 \mathrm{~km} \mathrm{NW}$ of Annecy, Haute-Savoie, Alpes Pays de Savoie, France (approx. geographical coordinates : $46^{\circ} 6^{\prime} 00^{\prime \prime} \mathrm{N}, 5^{\circ} 54^{\prime} 00^{\prime}$ ' E ; altitude : $700 \mathrm{~m}$ a.s.1.). The material (47 우, 37 juv.) was collected by P.M. in August and September 1997 from a well pumped for domestic purpose $\left(1000 \mathrm{~m}^{3}\right.$ day $\left.^{-1}\right)$. The well is $20 \mathrm{~cm}$ in diameter, $24.2 \mathrm{~m}$ deep, and the piezometric level changes from 11.0 to $17.5 \mathrm{~m}$ below the top of the well. The well has been dug in the Rhône River aquifer, in glacio-fluvial deposits of pebbles, gravels and sand. The site corresponds to an aquifer artificially recharged by surface water infiltrations from the Rhône River (for more details see description of the well F4 in Mallard et al. 1997).

Dissected specimens were mounted in glycerin on slides, with valves stored dry in micropalaeontological slides, whereas entire specimens were preserved in $97 \%$ ethanol in glass tubes. Valve dimensions were measured to the nearest $0.01 \mathrm{~mm}$ under the stereomicroscope at 500x. Valves and appendages were examined and drawn by the first author using a microscope fitted with a drawing tube at magnifications of $200 x$, 400x or 1000x (oil immersion).

The chaetotaxic notation adopted here follows the model proposed by Broodbakker \& Danielopol (1982), revised for the second antenna by Martens (1987), and for the thoracopods by Meisch (1996). Names for the limbs were used according to Meisch (2000). The nomenclature of Danielopol (1969), as reviewed by Meisch (2000), was used for the hemipenis morphology.

The statistical significance between various ratios of the limb characters and the carapace size of the females and juveniles from Gummer's How and Arcine was assessed with Mann-Whitney test (ratios) and Student's t-test (absolute values) using SigmaStat Statistical Software ver. 2.0.

Abbreviations used in the text, tables and figures : A - anterior ; a - outer lobe of hemipenis ; A1 - antennule ; A2 - antenna ; b - inner lobe of hemipenis ; cs - chelate seta ; D - distal ; $d$ - seta on Pr of L6; $d_{1}, d_{2}, d_{p}$ setae on Pr of L7 ; E - endopod ; e - setae on EI of L6 and L7 ; EI-EIV - 1st to 4th podomeres of E ; Ex - exterior ; Exo - exopod ; f - setae on EII of L6 and L7 ; Fu - furca (= uropod in Meisch 2000) ; g - setae on EIII of L6 and L7 ; G - claw ; $\mathrm{G}_{\mathrm{a}}$ - anterior claw of Fu ; $\mathrm{G}_{\mathrm{M}}$ $\left(\mathrm{G}_{\mathrm{m}}\right)$ - major (minor) claw on EIV of A2; $\mathrm{G}_{\mathrm{p}}$, - posterior claw of $\mathrm{Fu} ; \mathrm{G}_{1-3}$ - anterior and internal claws (or setae) on EIII of A2; H - height ; h - medial lobe of hemipenis ; $\mathrm{h}_{1-3}$ - setae (or claws) on EIV of L6 and L7 ; In - interior ; L - length ; $l$ - large (relative $\mathrm{L}$ of setae or claws) ; L5 - maxilliped (5th limb) ; L6 - walking leg (6th limb) ; L7 - cleaning leg (7th limb) ; LV - left valve; $\mathrm{M}$ - sclerotized internal process of hemipenis ; $m$ medium (relative L of setae or claws); Md - mandible (3rd limb) ; Mdp - mandibular palp ; Mx1 - maxillule (4th limb) ; P - posterior ; Pr - protopod ; RV - right valve ; $s$ - small (relative L of setae or claws) ; $\mathrm{s}_{\mathrm{a}}\left(\mathrm{s}_{\mathrm{p}}\right)$ anterior (posterior) seta of $\mathrm{Fu} ; \mathrm{S}_{1-2}$ - plumed cleaning setae on the 1 st podomere of Mdp $; \mathrm{t}_{1-4}$ - internal setae on EII of $\mathrm{A} 2$ ( $t_{2}$ and $t_{3}$ transformed in males into sensory bristles) ; W - width ; Y - aesthetasc on EI of A2 ; $\mathrm{y}_{1-3}$ - aesthetascs on EII, EIII and EIV of A2, respectively; $\mathrm{y}_{\mathrm{a}}$ - aesthetasc on the terminal podomere of A1 ; $\mathrm{z}_{1-3}$ - external setae (or claws) on EIII of A2; $\alpha, \beta, \gamma$ special setae on the 1st, 2nd and 3rd podomeres of Mdp, respectively. The lengths of podomeres used as reference for evaluation of the relative $\mathrm{L}$ of setae and claws of a given limb were measured in the middle of the podomeres. The podomeres selected as a basis for this comparison were as follows : A1 - 4th podomere, A2 - EI, Mdp - 3rd podomere, Mx1 palp - 2nd podomere, L6 - EII, L7 - EI. 


\section{Results}

Taxonomic position of Cryptocandona vavrai Kaufmann, 1900

Class : Ostracoda Latreille, 1806

Subclass : Podocopa Sars, 1866

Order : Podocopida Sars, 1866

Suborder : Cypridocopina Jones, 1901

Superfamily : Cypridoidea Baird, 1845

Family : Candonidae Kaufmann, 1900

Subfamily : Candoninae Kaufmann, 1900

Tribe : Candonini Kaufmann, 1900

Genus : Cryptocandona Kaufmann, 1900

\section{Emended diagnosis of Cryptocandona vavrai}

Valves with relatively broad calcified inner lamella at both ends (at the anterior end its $\mathrm{W}$ amounting up to $16.5 \%$ of valve $\mathrm{L}$ ). A 1 with the 2 nd and 3 rd podomeres of ramus (last five podomeres) relatively short and wide (shorter than 1st ramus podomere), 3rd ramus podomere lacking posterior seta. L7 with terminal short seta $\mathrm{h}_{1}$ hook-like and recurved downwards. Female genital lobe evenly rounded and inconspicuously protruded. Males very rare, to date single or few individuals are known from seven sites only. Right male clasping organ more developed, with relatively short distal finger and conspicuous swell distinctly rising up from the middle and gradually falling to distal end of dorsal margin of the organ. Left clasping organ slender, with almost straight dorsal margin and also short finger. Hemipenis: outer lobe (a) broadly extended, sub-triangular, inner lobe (b) distally blunt taper, medial lobe (h) with distal end similarly shaped as that of inner lobe, oriented to postero-ventral end of the body and partly overlapping inner lobe.

\section{Description of the male of Cryptocandona vavrai from Gummer's How}

LV viewed laterally (Fig. 2A) elongate, with greatest $\mathrm{H}$ situated behind mid-length at about $56 \%$ of $\mathrm{L}$ and slightly exceeding $1 / 2 \mathrm{~L}$ (see measurements below). RV (Fig. 2B) similar in outline to LV but slightly smaller and lower (see measurements), with greatest $\mathrm{H}$ located at $59 \%$ of L. LV overlapping RV along entire valve margin. Calcified part of inner lamella of both valves relatively broad, on anterior end representing $12-13 \%$ and on posterior $8 \%$ of valve L. Measurements: $\mathrm{LV}: \mathrm{L}=0.98 \mathrm{~mm}, \mathrm{H}=0.52 \mathrm{~mm}, \mathrm{H} / \mathrm{L}=0.53$; $\mathrm{RV}: \mathrm{L}=0.96 \mathrm{~mm}, \mathrm{H}=0.50 \mathrm{~mm}, \mathrm{H} / \mathrm{L}=0.52$.
A1 (Fig. 3A). I+II: A-2l, P-2l / III: A-1l / IV: A-1m, P-1m / V: A-2l, P-1m / VI: A-2l / VII: A-1m-2l, P-2l /

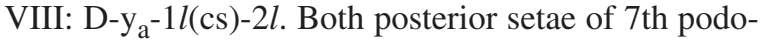
mere shorter than other large setae of this segment. L of aesthetasc $\mathrm{y}_{\mathrm{a}}$ equalling $2.0 \mathrm{x}$ terminal podomere $\mathrm{L}(\mathrm{L}$ of its sensory part ca. $0.2 \mathrm{x}$ of total $\mathrm{L}$ of this organ). Relative $\mathrm{L}$ of last five podomeres (IV-VIII) from proximal to distal as: $1.0: 0.8: 0.8: 0.9: 1.9$ and ratio $\mathrm{L} / \mathrm{W}$ of these podomeres, from proximal onwards as: 0.9 , $0.8,0.9,1.5,4.1$. L of largest anterior setae on penultimate podomere about $3.1-3.2 \times \mathrm{L}$ of ramus (last five podomeres combined).

A2 (Fig. 4A-B). Pr: P-1m / Exo: D(Ex)- $2 s-1 l /$ EI: PY, P(D)- $1 s-1 m$ / EII: A(D) $-2 s, \mathrm{P}-\mathrm{y}_{1}, \mathrm{D}(\mathrm{In})-1 s\left(\mathrm{t}_{4}\right)-$ $3 m\left(\mathrm{t}_{1}, \mathrm{t}_{2}, \mathrm{t}_{3}\right) / \mathrm{EIII}: \mathrm{D}(\mathrm{P})-\mathrm{y}_{2}, \mathrm{D}(\mathrm{A})-1 l\left(\mathrm{G}_{2}\right), \mathrm{D}(\mathrm{Ex})-$ $1 m\left(\mathrm{z}_{3}\right)-1 \mathrm{~m}\left(\mathrm{z}_{2}: \mathrm{G}\right)-1 l\left(\mathrm{z}_{1}: \mathrm{G}\right), \mathrm{D}(\mathrm{In})-1 s\left(\mathrm{G}_{1}: \mathrm{G}\right)-1 s\left(\mathrm{G}_{3}\right) /$ EIV: $\mathrm{D}(\mathrm{A})-1 m\left(\mathrm{G}_{\mathrm{M}}\right), \mathrm{D}(\mathrm{P})-\mathrm{y}_{3}-1 m, \mathrm{D}(\mathrm{Ex})-1 s\left(\mathrm{G}_{\mathrm{m}}\right)$, $\mathrm{D}(\mathrm{In})-1 s$. Relative $\mathrm{L}$ of anterior margin of EI : EII : EIII : EIV as: $1.0: 0.42: 0.33: 0.22$. L of aesthetasc Y equalling $0.4 \mathrm{x} \mathrm{L}$ of EI, sensory part of this organ representing about $0.5 x$ its L. Setae $t_{1}, t_{2}$ and $t_{3}$ almost equal and $0.6 \mathrm{x}$ as long as $\mathrm{EI}\left(\mathrm{t}_{2}\right.$ and $\mathrm{t}_{3}$ transformed into male bristles), $\mathrm{t}_{4}$ rudimentary and almost not visible. Relative L of claws, some setae and remaining aesthetascs compared with $\mathrm{L}$ of EI as: $\mathrm{G}_{1}$ (claw) $=0.5, \mathrm{G}_{2}$ $($ claw $)=1.2-1.3, \mathrm{G}_{3}($ seta $)=0.5, \mathrm{z}_{1}($ claw $)=1.0-1.1, \mathrm{z}_{2}$ $($ claw $)=0.7, \mathrm{z}_{3}($ seta $)=0.5-0.6, \mathrm{G}_{\mathrm{M}}($ claw $)=1.0, \mathrm{G}_{\mathrm{m}}$ (claw) $=0.4-0.5, \mathrm{y}_{1}=0.2, \mathrm{y}_{2}=0.2, \mathrm{y}_{3}$ (basally fused with adjoining seta) $=0.6$.

Rake-like organ with 9-10 teeth.

Md (Fig. 3B). Masticatory part of coxa: laterally with one relatively long seta, distally with seven gradually diminishing stout teeth with groups of diverse setae, and ventrally with one plumed seta. Mdp: I: In- $1 s(\alpha)$ $1 s\left(\mathrm{~S}_{2}\right)-1 m-1 m\left(\mathrm{~S}_{1}\right) /$ II: Ex-1m-1l, In- $1 s(\beta)-1 l-3 l$ (setal group) / III: Ex-3m, In-2s-2m, D-1m( $\gamma)-1 m$ / IV: D-4s$2 m(\mathrm{G})$. First podomere with small respiratory plate. Gamma $(\gamma)$ seta not clearly different in shape and length from adjoining distal seta. L of both claws of terminal podomere about $1.3 \mathrm{x} \mathrm{L}$ of $3 \mathrm{rd}$ palp podomere.

Mx1 bearing elongated respiratory plate and consists of three masticatory endites and two-segmented palp (Fig. 3C): I: Ex-1m-3l / II: D- $4 m-2 m$ (cs). Relative L of three distal setae on 2nd podomere may be also evaluated as short while $\mathrm{L}$ of distal chelate setae as large.

L5 (Fig. 5B). Pr carrying two anterior sub-equal setae (a) and two exterior setae (b and d). Endite apically with group of 14 setae. Respiratory plate consisting of three plumed filaments. E developed into asymmetrical, prehensile palps. Right palp (Fig. 5B) more developed, with relatively short distal finger and conspi- 

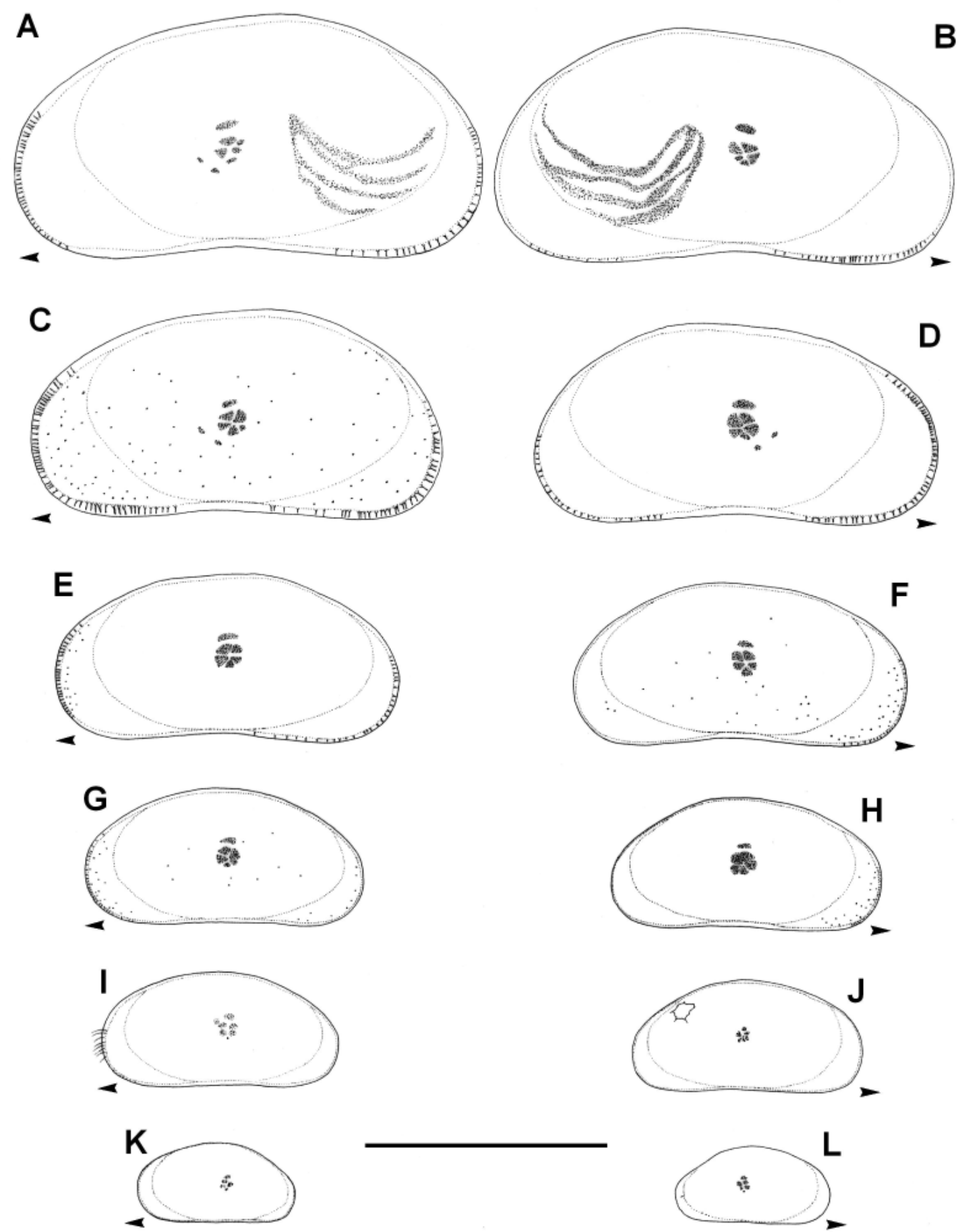

Fig. 2. Cryptocandona vavrai Kaufmann, 1900 ; Gummer's How, UK ; valves viewed laterally : A-male LV ; B-male RV ; C-female LV ; D-female RV ; E-8th stage juv. LV; F-8th stage juv. RV ; G-7th stage juv. LV ; H-7th stage juv. RV ; I-6th stage juv. LV ; J-6th stage juv. RV ; K5th (?) stage juv. LV ; L-5th (?) stage juv. RV. Scale bar : $500 \mu \mathrm{m}$. 


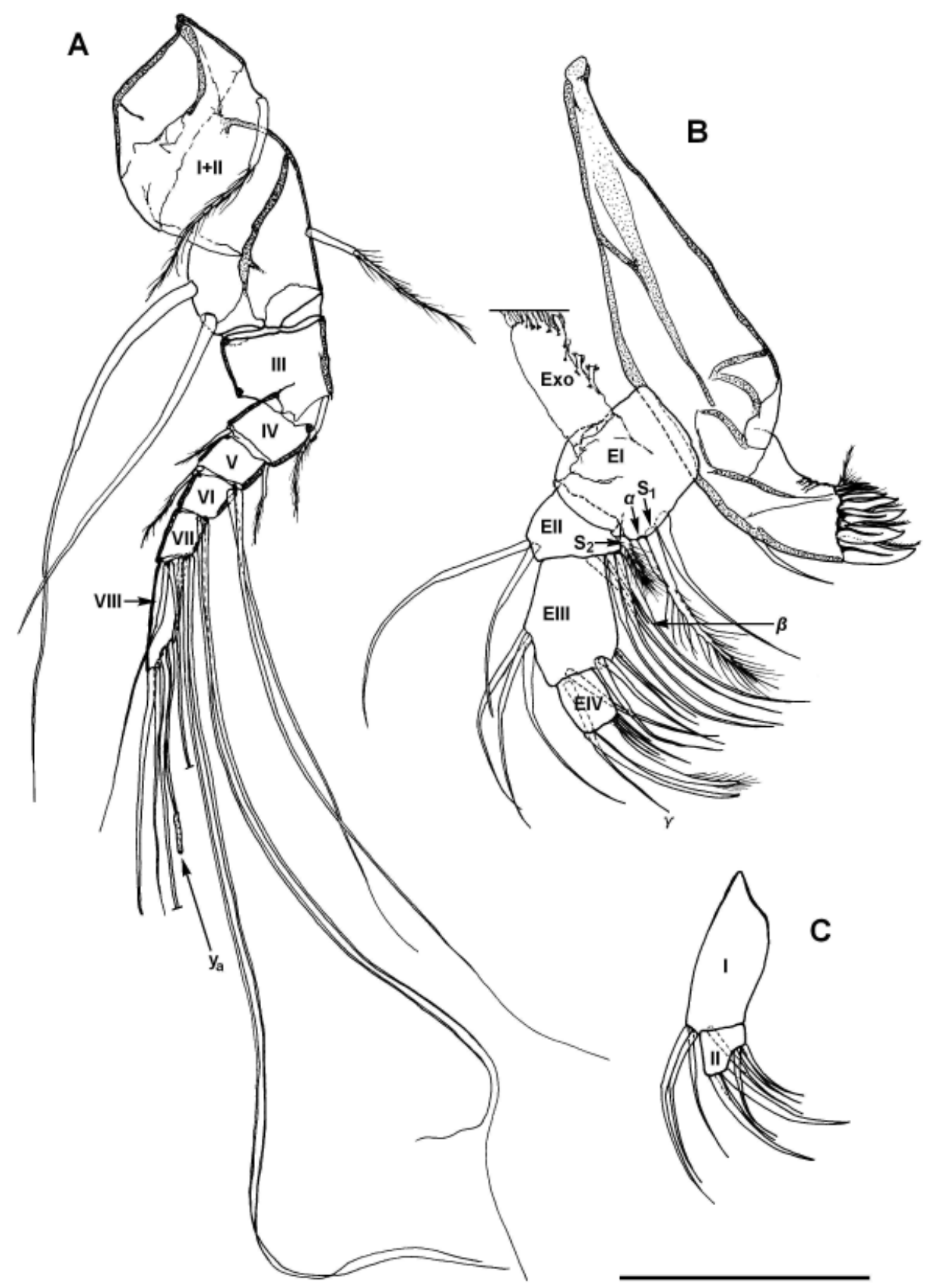

Fig. 3. Cryptocandona vavrai Kaufmann, 1900 ; Gummer's How, UK (male) : A-A1 ; B-Md ; C-Mx1 palp. Scale bar: $100 \mu \mathrm{m}$

cuous swell distinctly rising up from the middle and gradually falling to distal end of dorsal margin of this organ. Left palp (Fig. 5A) slender, with almost straight dorsal margin and also short finger.
L6 (Fig. 6B). Pr: A(D)-1s(d 2 / EI: A(D)-1s(e) / EII: A(D)- $1 s(\mathrm{f}) /$ EIII: A(D)- $2 s(\mathrm{~g}) / \mathrm{EIV}: \mathrm{P}(\mathrm{D})-1 s\left(\mathrm{~h}_{3}\right), \mathrm{D}-$ $1 s\left(\mathrm{~h}_{1}\right)-1 l\left(\mathrm{~h}_{2}: \mathrm{G}\right)$. Terminal claw $\left(\mathrm{h}_{2}\right)$ equaling $2.4 \mathrm{x} \mathrm{L}$ of EII. Other L6 aberrant (Fig. 6A), lacking one endopo- 
A
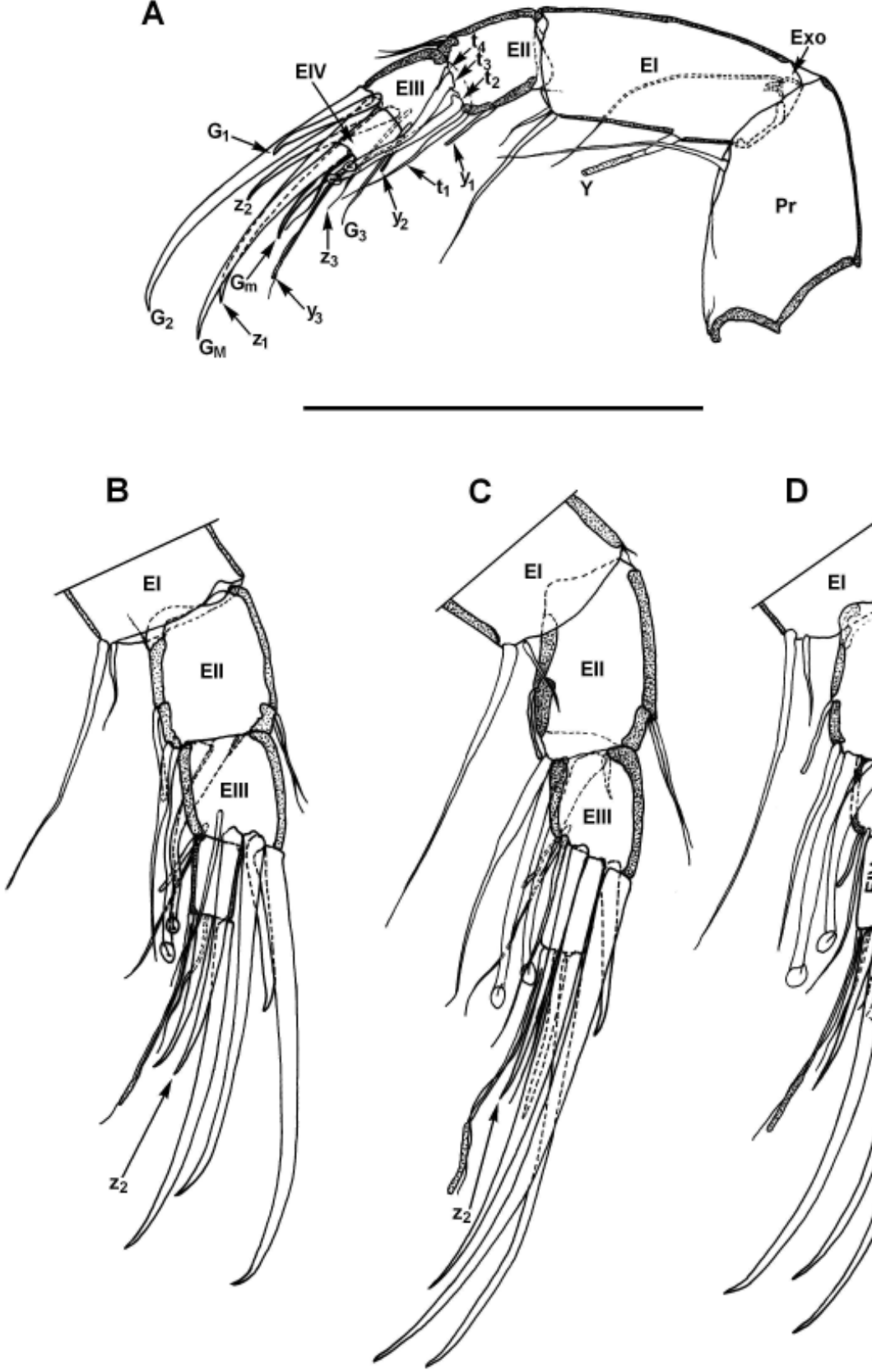

D

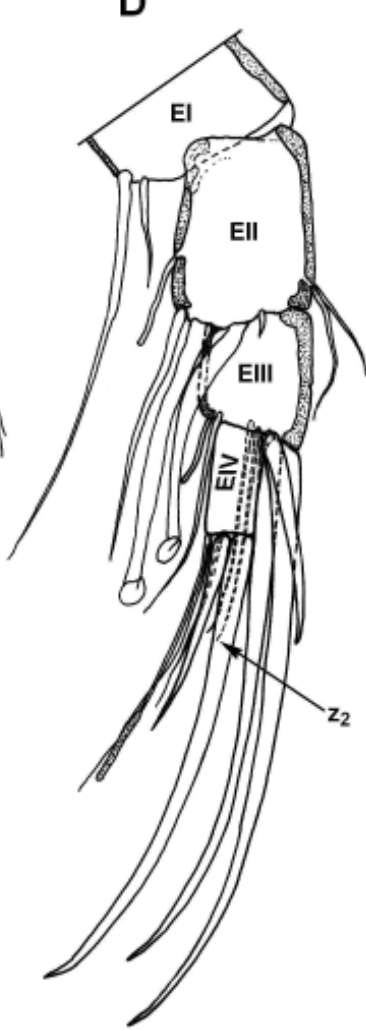

Fig. 4. Cryptocandona vavrai Kaufmann, 1900 (male) : A-right A2 in internal view (Gummer's How) ; Bapical chaetotaxy of right A2 in external view (Gummer's How) ; C-apical chaetotaxy of right A2 in external view (Ille-sur-Têt) ; D-apical chaetotaxy of left A2 in internal view (Slănic-Moldova). Scale bar : $143 \mu \mathrm{m}$ for $\mathrm{A}, 100 \mu \mathrm{m}$ for B and D, $105 \mu \mathrm{m}$ for C.

dial podomere and almost all endopodial setae as well as differing from its counterpart with respect to $\mathrm{L}$ of corresponding podomeres. Aberrant L6 resembles walking leg of 6th stage juveniles.
L7 (Fig. 6C). Pr: Ex- $2 m\left(\mathrm{~d}_{1}, \mathrm{~d}_{2}\right)$, In- $1 l\left(\mathrm{~d}_{\mathrm{p}}\right) /$ EI: P$1 m(\mathrm{e}) /$ EII: P-1m(f) / EIII: P-1 $m(\mathrm{~g}) / \mathrm{EIV}: \mathrm{D}-1 s\left(\mathrm{~h}_{1}\right)-$ $1 m\left(\mathrm{~h}_{2}\right)-1 l\left(\mathrm{~h}_{3}\right)$. Endopodial podomeres EII and EIII fu- 


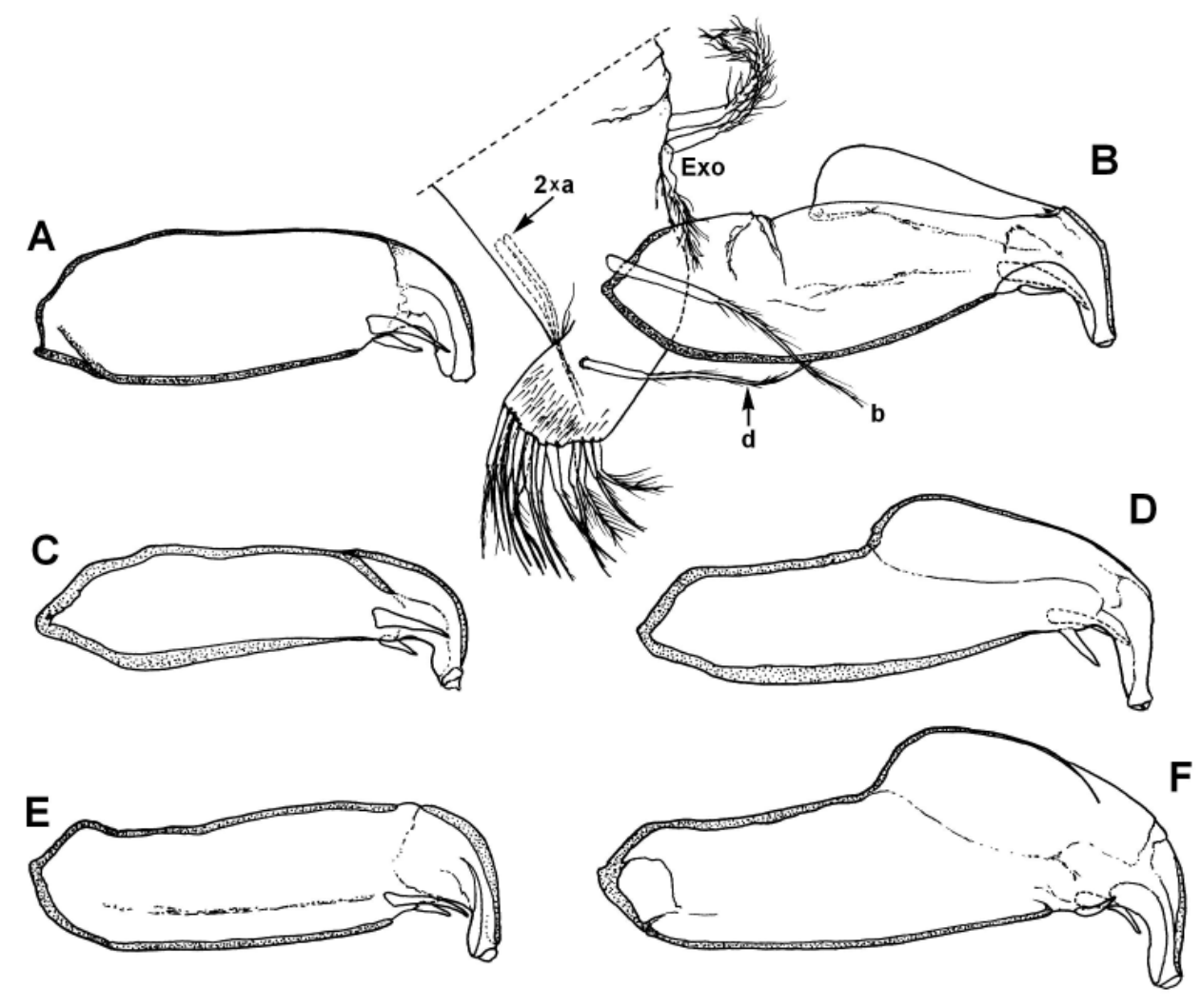

Fig. 5. Cryptocandona vavrai Kaufmann, 1900 (male) : A-left prehensile palp (Gummer's How) ; B-right L5 (Gummer's How) ; C-left prehensile palp (Ille-sur-Têt) ; D-right prehensile palp (Ille-sur-Têt); E-left prehensile palp (Slănic-Moldova) ; F-right prehensile palp (Slănic-Moldova). Scale bar : $100 \mu$ m.

sed. Penultimate podomere with row of fine setulae on the postero-distal end, just above the distal seta $\mathrm{g}$. The shortest apical seta $\left(\mathrm{h}_{1}\right)$ hook-like and recurved downwards. Relative L of three apical setae as: $\mathrm{h}_{1}=0.2 \mathrm{x}, \mathrm{h}_{2}$ $=0.7 \mathrm{x}, \mathrm{h}_{3}=1.8 \mathrm{x} \mathrm{L}$ of EI.

Fu and its attachment (Fig. 6D). Ramus almost straight. Ratio of $L$ of anterior margin, $s_{a}, G_{a}, G_{p}, s_{p}$ and distance between insertion points of $s_{p}$ and $G_{p}$ as: $1: 0.2: 0.5: 0.4-0.5: 0.1-0.2: 0.3$.

Hemipenis (Fig. 6E). Outer lobe (a) broadly extended, sub-triangular, inner lobe (b) distally blunt taper, medial lobe (h) with distal end similarly shaped as that of the inner lobe, oriented to postero-ventral end of the body and partly overlapping inner lobe. M process with elongated distal part.

Zenker's organ with seven internal rings of spines, its $\mathrm{L}$ represents about $30 \%$ of carapace $\mathrm{L}$.

\section{Carapace shape and size of juvenile specimens}

As an addition to the description of the species, the shape of the valves and carapaces of the last four juvenile stages from Gummer's How are shown in Fig. 2E$\mathrm{L}$, whereas the carapace sizes of the last three juvenile stages from both Gummer's How and Arcine are compared in Table 1.

\section{Discussion}

Comparison of the males from Ille-sur-Têt and from Slănic-Moldova with that from Gummer's How

Carapace. The IT male is significantly smaller $(\mathrm{L}=$ $0.90 \mathrm{~mm}, \mathrm{H}=0.48 \mathrm{~mm}, \mathrm{H} / \mathrm{L}=0.53$ ) whereas the $\mathrm{SM}$ male larger $(\mathrm{L}=1.02 \mathrm{~mm}, \mathrm{H}=0.53, \mathrm{H} / \mathrm{L}=0.52)$ than that from $\mathrm{GH}$ (see measurements above). However, the 


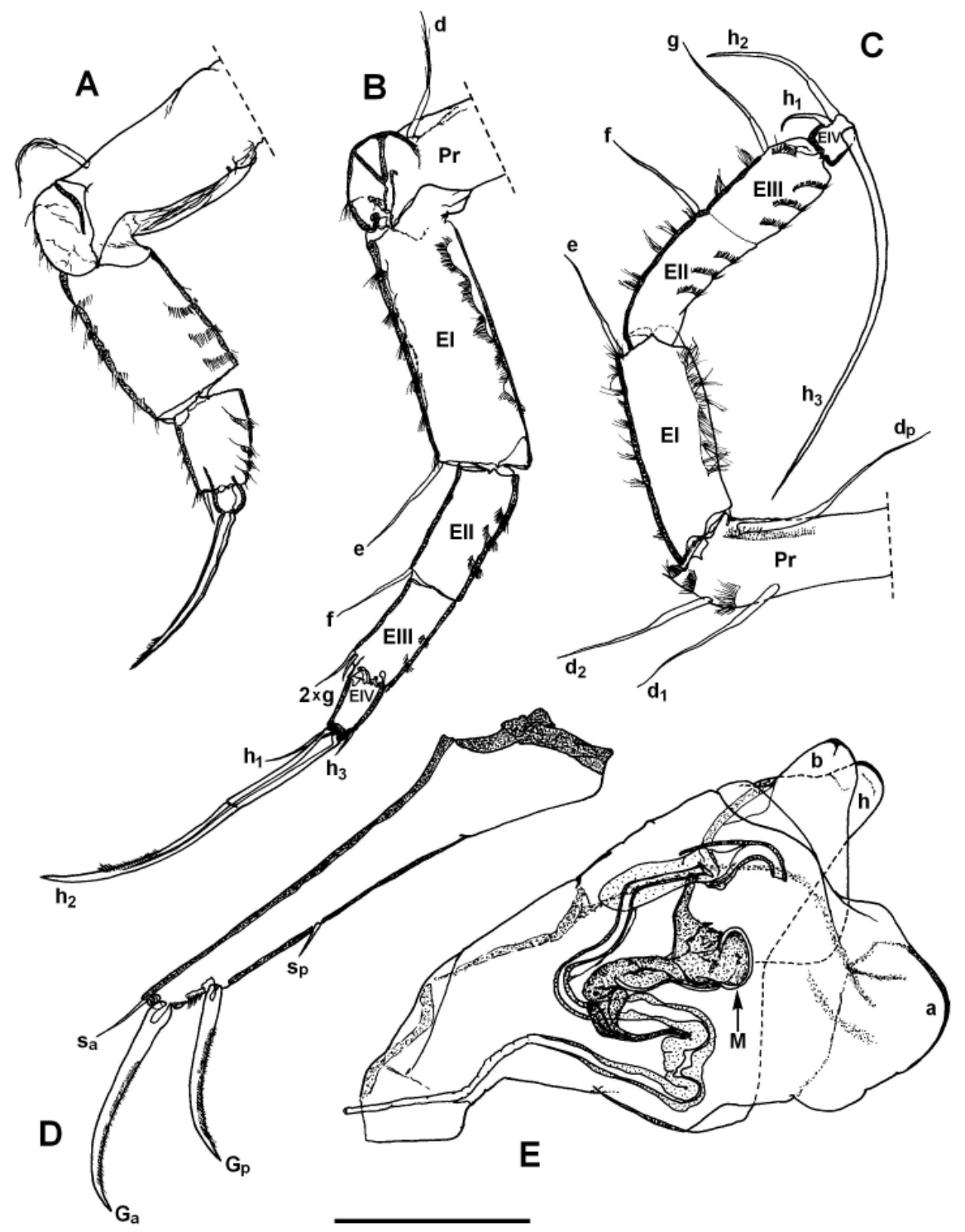

Fig. 6. Cryptocandona vavrai Kaufmann, 1900 ; Gummer's How, UK (male) : A-aberrant L6; B-fully developed L6 ; C-L7 ; D-Fu ; E-right hemipenis in external view. Scale bar : $100 \mu \mathrm{m}$ for A-D, $67 \mu \mathrm{m}$ for $\mathrm{E}$.

$\mathrm{H} / \mathrm{L}$ ratio in all three males was nearly the same.

A1. The IT male possesses a noticeably longer anterior seta of IV podomere (large in length) than that of both other males (medium). The largest anterior setae on the penultimate podomere are slightly shorter in both the IT (about 2.8x the ramus) and the SM male (about 2.6x the ramus) than those in the GH male (about 3.1-3.2x the ramus). The SM male has distinctly more elongated podomeres (especially the last three), therefore the ratios $\mathrm{L} / \mathrm{W}$ of these podomeres, from proximal onwards, are in the SM male as: 1.1, $1.0,1.3,1.9,6.5$.

A2. The major difference recorded among the compared males referred to the degree of the development of the claw $z_{2}$ on EIII (Fig. 4A-D). In the SM male it is a relatively short claw-like seta (0.4-05x the L of EI) whereas in two other males - a medium in length claw 
Table 1. The differences in carapace length $(\mathrm{L}$ in $\mathrm{mm})$ and height $(\mathrm{H}$ in $\mathrm{mm})$ compared by Student's t-test $(\mathrm{t})$ as well as the differences in height to length ratio $(\mathrm{H} / \mathrm{L})$ compared by Mann-Whitney test among females and the last three juvenile stages from Gummer's How and Arcine $(n=$ number of specimens, $\mathrm{SD}=$ standard deviation, probability level : $*=0.01<\mathrm{p} \leq 0.05, * *=0.001<\mathrm{p} \leq 0.01, * * *=\mathrm{p} \leq 0.001$, n.s. $=$ not significant $)$.

\begin{tabular}{|c|c|c|c|c|c|}
\hline & & \multicolumn{2}{|l|}{ Gummer's How } & Arcine & \multirow{2}{*}{$\begin{array}{l}\text { Statistical } \\
\text { difference }\end{array}$} \\
\hline & & mean $\pm \mathrm{SD} \quad$ (range) & $\mathbf{n}$ & mean $\pm \mathrm{SD}$ & \\
\hline \multirow{3}{*}{ 90 } & $\mathrm{L}$ & $0.87 \pm 0.01(0.84-0.88)$ & 25 & $0.84 \pm 0.02(0.80-0.88) 47$ & $t=7.163^{* * *}$ \\
\hline & $\mathrm{H}$ & $0.45 \pm 0.01(0.43-0.47)$ & 25 & $0.42 \pm 0.01(0.39-0.43) 47$ & $\mathrm{t}=11.545^{* * *}$ \\
\hline & $\mathrm{H} / \mathrm{L}$ & $0.52 \pm 0.01(0.50-0.53)$ & 25 & $0.50 \pm 0.01(0.48-0.52) 47$ & $\mathrm{U}=1392.0^{* * *}$ \\
\hline \multirow{3}{*}{$\begin{array}{l}\text { 8th stage } \\
\text { juveniles }\end{array}$} & $\mathrm{L}$ & $0.73 \pm 0.01(0.72-0.73)$ & 4 & $0.70 \pm 0.01(0.69-0.72) 8$ & $\mathrm{t}=3.452^{* *}$ \\
\hline & $\mathrm{H}$ & $0.36 \pm 0.01(0.35-0.37)$ & 4 & $0.34 \pm 0.01(0.33-0.35) 8$ & $t=2.418^{*}$ \\
\hline & $\mathrm{H} / \mathrm{L}$ & $0.49 \pm 0.02(0.48-0.51)$ & 4 & $0.49 \pm 0.01(0.48-0.49) 8$ & $\mathrm{U}=28.0 \mathrm{n} . \mathrm{s}$ \\
\hline \multirow{3}{*}{$\begin{array}{l}7 \text { th stage } \\
\text { juveniles }\end{array}$} & $\mathrm{L}$ & 0.57 & 1 & $0.56 \pm 0.01(0.55-0.57) 8$ & - \\
\hline & $\mathrm{H}$ & 0.27 & 1 & $0.27 \pm 0.01(0.27-0.28) 8$ & - \\
\hline & $\mathrm{H} / \mathrm{L}$ & 0.47 & 1 & $0.48 \pm 0.01(0.47-0.49) 8$ & - \\
\hline \multirow{3}{*}{$\begin{array}{l}6 \text { th stage } \\
\text { juveniles }\end{array}$} & $\mathrm{L}$ & $0.50 \pm 0.01(0.49-0.50)$ & 2 & $0.47 \pm 0.01(0.46-0.49) 10$ & $\mathrm{t}=2.874^{*}$ \\
\hline & $\mathrm{H}$ & $0.25 \pm 0.01(0.24-0.25)$ & & $0.24 \pm 0.01(0.23-0.25) 10$ & $\mathrm{t}=1.328 \mathrm{n} . \mathrm{s}$ \\
\hline & $\mathrm{H} / \mathrm{L}$ & $0.50 \pm 0.01(0.49-0.50)$ & & $0.51 \pm 0.01(0.48-0.52) 10$ & $\mathrm{U}=7.5 \mathrm{n} . \mathrm{s}$ \\
\hline
\end{tabular}

(0.6-0.7x of the L of EI). Underdevelopment of the $z_{2}$ claw in the SM male may be considered a result of paedomorphosis. In the last stage juveniles of the superfamily Cypridoidea the $\mathrm{z}_{2}$ is a seta, which after the last moult transforms into a well developed claw in males, while in females it retains a seta (Meisch 2000). Similar case was already documented and explained as a result of the neotenic process by Namiotko et al. (2001) in the males of Cryptocandona dudichi (Klie) and by Namiotko et al. (2005) in the males of Cryptocandona kieferi (Klie). In that former species males found in a cave exhibited a reduced $\mathrm{z}_{2}$ seta, while those collected in surrounding springs had the fully developed $\mathrm{z}_{2}$ claw. As the SM male was collected from porous groundwater reached through a well, whereas the GH male was from surface waters, it seems that the neoteny affects more commonly stygobitic populations (species) than those living in the epigean habitats. Apart from the $\mathrm{z}_{2}$ claw/seta difference, the SM male has slightly larger $\mathrm{z}_{1}$ claw (1.2x the L of EI versus 1.0-1.1x in the GH male), aesthetasc $\mathrm{Y}(0.5 \mathrm{x}$ versus $0.4 \mathrm{x}$ in the $\mathrm{GH}$ male $)$ and outer seta on the postero-distal end of EI $(0.9 \mathrm{x}$ versus $0.8 x$ in the $\mathrm{GH}$ male). In contrast, some claws and setae in the IT male are smaller than those in the GH male: $G_{1}(0.4 x$ the $L$ of EI vs. $0.5 x$ in the $\mathrm{GH}$ male $), z_{2}$ ( $0.6 \mathrm{x}$ vs. $0.7 \mathrm{x}$ in the $\mathrm{GH}$ male) and also outer seta on the postero-distal end of EI $(0.7 \mathrm{x})$.

Mdp. One additional short seta is present on the dis- tal margin of the 3rd podomere of one palp in the SM male (III: D- $1 s-1 m(\gamma)-1 m)$; the corresponding palp of this individual has typically two medium distal setae as in the other species in the genus Cryptocandona.

L5 (Fig. 5A-F). A slight difference could only be noticed in the outline of the median margin of the inflated part of the right clasping organ of the SM male (more rounded) as compared with that of the GH male (almost straight or even slightly concave).

L6. Terminal claw (h2) slightly shorter in both IT male (2.3x the L of EII) and the SM male (2.1x of the L of EII) as compared with that of the GH male $(2.4 \mathrm{x}$ the L of EII).

L7. The $d_{p}$ seta slightly shorter in the IT and SM males (medium in length) than that of the $\mathrm{GH}$ male (large), and the distal setae of EI-EIII (e, f and g, respectively) in the SM male relatively shorter than those medium in length of both other males. The IT male has also shorter apical seta $h_{2}(0.5-0.6 x$ the $L$ of EI) than that of both other males $(0.7 x$ the $\mathrm{L}$ of $\mathrm{EI})$.

Zenker's organ relatively larger in both the IT and SM males (around $38-43 \%$ of the carapace L) than that of the GH male $(30 \%)$.

All the differences mentioned above are considered to rank within the variability range of the males of Cryptocandona vavrai. 


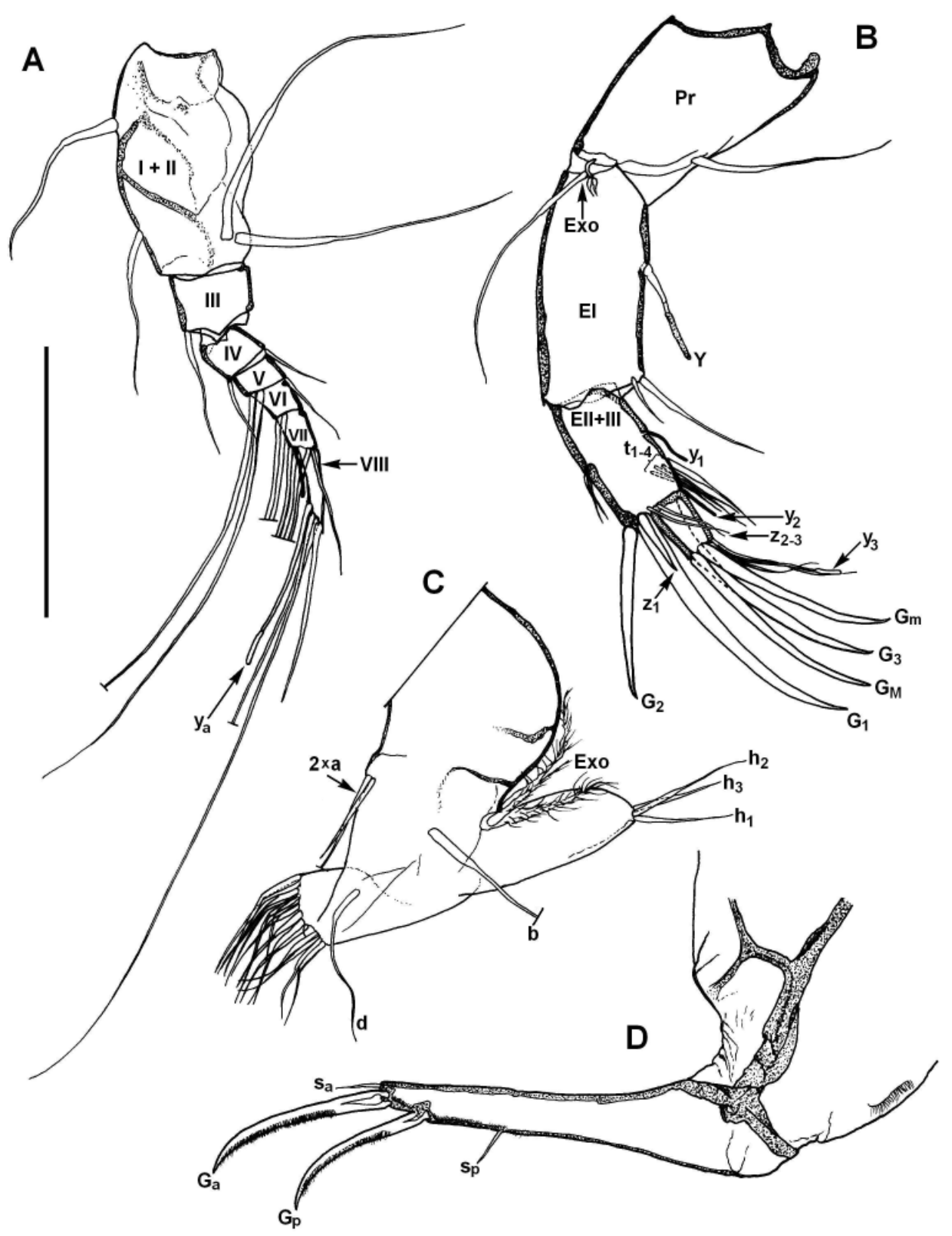

Fig. 7. Cryptocandona vavrai Kaufmann, 1900 ; Gummer's How, UK (female) : A-A1; B-left A2 in external view ; C-L5 ; D-Fu and genital lobe. Scale bar : $100 \mu \mathrm{m}$ for A-C, $150 \mu \mathrm{m}$ for D.

Comments on the previous descriptions of the male of Cryptocandona vavrai

Klie's (1938) description is seriously incomplete as the author depicted only the carapace, the left clasping organ and the hemipenis. Eichhorn (1968) described and illustrated almost all limbs but his description of some limbs was inadequate and on some points certainly erroneous. Some anomalies of his description have been clarified and incompleteness filled by comparing and fully describing our male individuals. We consider all differences between our description and that of Eichorn (1968) to be due to inaccuracies of Eichhorn's observations. 
Finally, one more description of males assigned to Cryptocandona vavrai has to be discussed. Altinsaçli (1997) reports the finding of numerous males collected in the inflow of the Esme stream into Lake Sapanca situated in NW Turkey. However, his illustration of A2 (Altinsaçli 1997: Fig. 5b) shows EII and EIII not differentiated and without male bristles. What is more, L7 is figured (Altinsaçli 1997: Fig. 5i) with the chaetotaxic pattern utterly atypical for the genus Cryptocandona (missing setae $\mathrm{d}_{1}, \mathrm{~d}_{2}$, e and $\mathrm{f}$ ) and with seta $\mathrm{h}_{1}$ straight, not recurved, and longer than reported for $C$. vavrai. Furthermore, neither the morphology of the hemipenis nor the shape of clasping organs (cf. Altinsaçli 1997: Fig. 5j, 5f and 5g) conforms to the previous (Klie 1938, Eichhorn 1968) and present descriptions of these organs in the males of $C$. vavrai. In conclusion, we consider that these males certainly belong to a different species.

\section{Description of the females from Gummer's How and comparison with the males}

Carapace. The valve shapes do not display any significant differences between the sexes (compare Fig. 2A-B and Fig. 2C-D), however, the carapace size is sexually dimorphic, i.e. females are significantly smaller (compare data in Table 1 for the size of females with the measurements for the males given above).

A1 (Fig. 7A). Arrangement of setae as in the males. Both the females and the males lack the posterior seta on the VIth podomere. As this seta is present in the remaining species of the genus Cryptocandona, this pe- culiarity is a good diagnostic character of $C$. vavrai. It was recorded for the first time by Danielopol (1978) and subsequently confirmed and verify for the other Cryptocandona species by Namiotko \& Danielopol (2002). Length ratios of last five podomeres, their L/W ratios and $\mathrm{L}$ of largest setae on penultimate podomere are presented in Table 2. Terminal podomere more elongated $(\mathrm{L} / \mathrm{W}$ ratio $=4.4-4.9)$ as compared with the males from GH and IT (4.0-4.1).

A2 (Fig. 7B). Pr: P-1m / Exo: D(Ex)- $2 s-1 l$ / EI: P-Y, $\mathrm{P}(\mathrm{D})-1 s-1 m / \mathrm{E}(\mathrm{II}+\mathrm{III}): \mathrm{A}-2 s, \mathrm{P}-\mathrm{y}_{1}, \mathrm{P}(\mathrm{In})-3 s\left(\mathrm{t}_{2}, \mathrm{t}_{3}, \mathrm{t}_{4}\right)-$ $1 m\left(\mathrm{t}_{1},\right), \mathrm{D}(\mathrm{A})-1 m\left(\mathrm{G}_{2}\right), \mathrm{D}(\mathrm{P})-\mathrm{y}_{2}, \mathrm{D}(\mathrm{Ex})-3 s\left(\mathrm{z}_{1}: \mathrm{G}, \mathrm{z}_{2}, \mathrm{z}_{3}\right)$, $\mathrm{D}(\mathrm{In})-2 l\left(\mathrm{G}_{1}, \mathrm{G}_{3}\right) / \mathrm{EIV}: \mathrm{D}(\mathrm{A})-1 m\left(\mathrm{G}_{\mathrm{M}}\right), \mathrm{D}(\mathrm{P})-\mathrm{y}_{3}-1 m$, $\mathrm{D}(\mathrm{Ex})-1 m\left(\mathrm{G}_{\mathrm{m}}\right), \mathrm{D}(\mathrm{In})-1 s($ or $m)$. In some females relative $L$ of $t_{2}$ seta could be evaluated as medium. Aesthetasc $\mathrm{y}_{3}$ fused at base with another seta and its $\mathrm{L}$ equalling $0.6 x$ L of EI. Relative L of claws, selected setae and other aesthetascs are shown in Table 3.

Mdp without sexual dimorphism but slight differences in relative $\mathrm{L}$ of two setae on external margin of 2nd palp podomere which are medium in $\mathrm{L}$ versus one medium and one large in the males.

Mx1 palp without sexual dimorphism excepting insignificant differences in relative L of some setae: I: Ex-3m- $1 l$ or $2 m-2 l$ or $1 m-3 l /$ II: D- $3 s-1 m-2 m(\mathrm{cs})$ or $2 s-2 m-2 m(\mathrm{cs})$.

L5 (Fig. 7C). Pr and respiratory plate as in the males. Palp-shaped E with three apical sub-equal setae.

L6 as in the males. The variability of the relative $\mathrm{L}$ of the $\mathrm{h}_{2}$ claw is given in Table 4 .

Table 2. The differences in various ratios taken on the first antenna of females from Gummer's How and Arcine compared by Mann-Whitney U-test $(\mathrm{LIV}$, LV, LVI... = the length of 4th, 5th, 6 th... podomere, $1 \mathrm{~s}=$ the length of the largest setae on the penultimate podomere, $\mathrm{L} / \mathrm{W}=$ length to width ratio of a given podomere, $\mathrm{n}=$ number of specimens, ramus $=$ the length of the last five podomeres combined, $\mathrm{SD}=$ standard deviation, probability level: $*=0.01<\mathrm{p} \leq 0.05$, $* *=0.001<\mathrm{p} \leq 0.01, * * *=\mathrm{p} \leq 0.001, \mathrm{n} . \mathrm{s} .=$ not significant $)$.

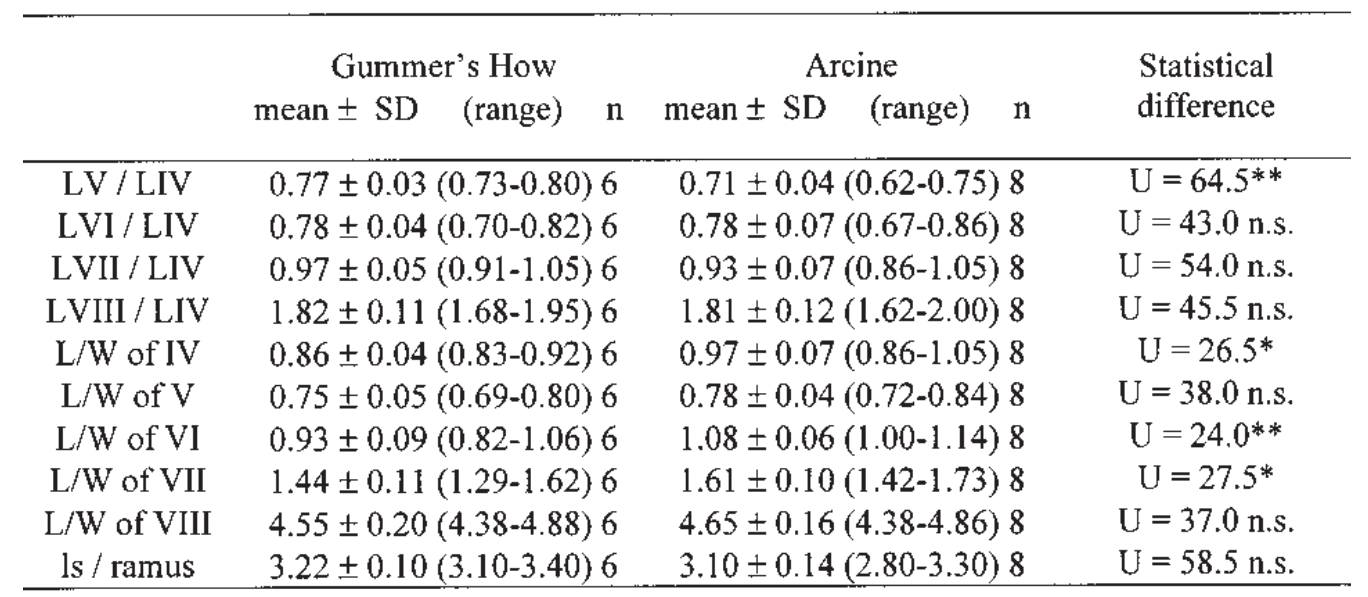


Table 3. The differences in the relative length of various claws, setae and aesthetascs on the second antenna of females from Gummer's How and Arcine compared by Mann-Whitney U-test $(\mathrm{EI}=$ the length of the 1 st endopodial podomere, $\mathrm{n}=$ number of specimens, $\mathrm{SD}=\mathrm{standard}$ deviation, probability level : $*=0.01<\mathrm{p} \leq 0.05, * *=0.001<\mathrm{p} \leq 0.01$, $* * *=\mathrm{p} \leq 0.001$, n.s. $=$ not significant).

\begin{tabular}{|c|c|c|c|}
\hline & Gummer's How & Arcine & \multirow{2}{*}{$\begin{array}{l}\text { Statistical } \\
\text { difference }\end{array}$} \\
\hline & mean $\pm \mathrm{SD}$ & mean $\pm \mathrm{SD}$ & \\
\hline $\mathrm{G}_{\mathrm{L}}$ claw / EI & $1.27 \pm 0.04(1.22-1.32) 6$ & $1.38 \pm 0.06(1.27-1.45) 7$ & $\mathrm{U}=24.0^{* *}$ \\
\hline $\mathrm{G}_{2}$ claw / EI & $0.74 \pm 0.02(0.73-0.77) 6$ & $0.78 \pm 0.02(0.75-0.81) 8$ & $\mathrm{U}=26.0^{*}$ \\
\hline $\mathrm{G}_{3}$ claw $/ \mathrm{EI}$ & $1.14 \pm 0.05(1.08-1.20) 6$ & $1.25 \pm 0.07(1.12-1.35) 8$ & $\mathrm{U}=26.5^{*}$ \\
\hline $\mathrm{z}_{\mathrm{j}}$ claw / $\mathrm{EI}$ & $0.33 \pm 0.01(0.30-0.33) 6$ & $0.34 \pm 0.02(0.31-0.36) 8$ & $\mathrm{U}=27.5^{*}$ \\
\hline $\mathrm{G}_{\mathrm{M}}$ claw $/ \mathrm{EI}$ & $0.93 \pm 0.04(0.88-0.97) 6$ & $1.07 \pm 0.02(1.05-1.09) 8$ & $\mathrm{U}=21.0^{* * *}$ \\
\hline $\mathrm{G}_{\mathrm{m}}$ claw $/ \mathrm{EI}$ & $0.67 \pm 0.02(0.64-0.68) 6$ & $0.77 \pm 0.02(0.75-0.81) 8$ & $\mathrm{U}=21.0^{* * *}$ \\
\hline $\mathrm{t}_{1}$ seta $/ \mathrm{EI}$ & $0.53 \pm 0.02(0.49-0.55) 6$ & $0.46 \pm 0.05(0.39-0.53) 5$ & $\mathrm{U}=17.5^{*}$ \\
\hline $\mathrm{Y} / \mathrm{EI}$ & $0.42 \pm 0.01(0.41-0.44) 6$ & $0.52 \pm 0.02(0.49-0.55) 8$ & $\mathrm{U}=21.0^{* * *}$ \\
\hline
\end{tabular}

Table 4. The differences in the relative length of various claws and setae on the walking leg (L6), cleaning leg (L7) and furca of females from Gummer's How and Arcine compared by Mann-Whitney U-test (AM = anterior margin of fur$\mathrm{ca}, \mathrm{EI}(\mathrm{EII})=$ the length of $1 \mathrm{st}(2 \mathrm{nd})$ endopodial podomere, $\mathrm{G}_{\mathrm{p} \text {-sp }}=$ the length of the distance between the insertion points of the $\mathrm{G}_{\mathrm{p}}$ claw and $\mathrm{s}_{\mathrm{p}}$ seta, $\mathrm{n}=$ number of specimens, $\mathrm{SD}=$ standard deviation, probability level : $*=0.01<\mathrm{p}$ $\leq 0.05, * *=0.001<\mathrm{p} \leq 0.01, * * *=\mathrm{p} \leq 0.001$, n.s. $=$ not significant).

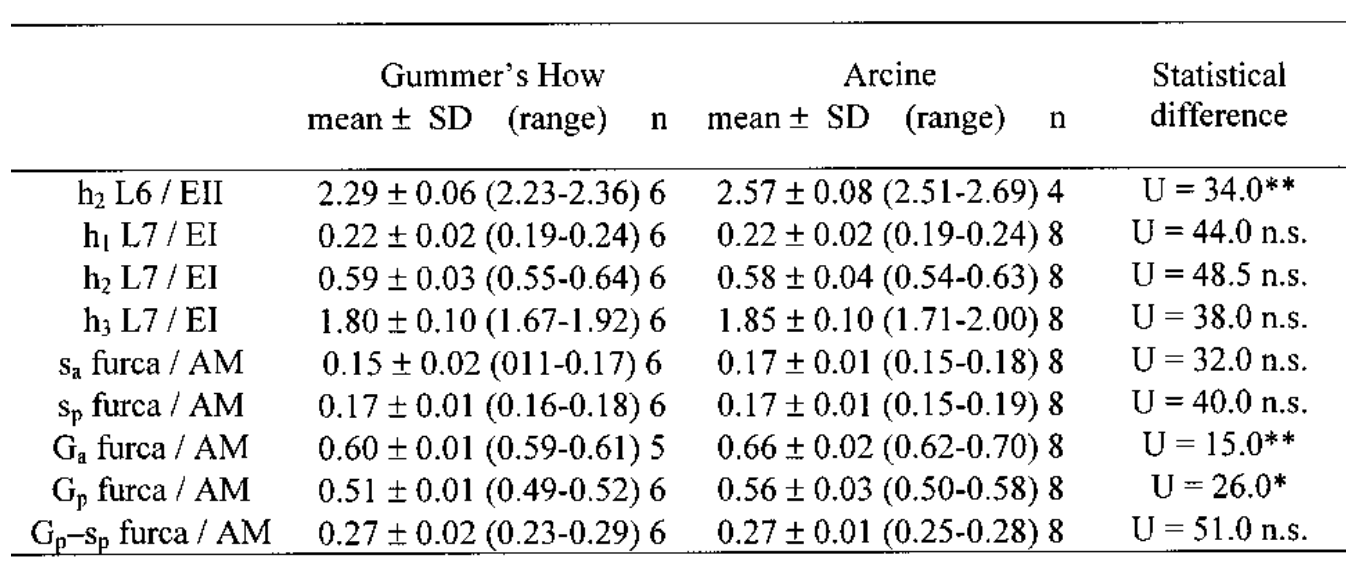

L7 without sexual dimorphism. EII and EIII in some females weakly separated. Variability ranges of relative $L$ of three apical setae are shown in Table 4.

Fu, its attachment and genital lobe (Fig. 7D). Genital lobe evenly rounded and inconspicuously protruded. The claw $\mathrm{G}_{\mathrm{a}}$ relatively longer than that in the males (compare the data for the females in Table 4 with those above for the males).

Comparison between the females from Gummer's How and those from Arcine

Carapace size. Females from AR appear to be on average slightly smaller (mean $\mathrm{L}=0.84 \mathrm{~mm}$, mean $\mathrm{H}$ $=0.42 \mathrm{~mm}$ ) and more elongated (less compact) (mean
$\mathrm{H} / \mathrm{L}$ ratio $=0.50)$ than those from $\mathrm{GH}($ mean $\mathrm{L}=0.87$ $\mathrm{mm}$, mean $\mathrm{H}=0.45 \mathrm{~mm}$, mean $\mathrm{H} / \mathrm{L}=0.52$ ). Although the statistical comparisons of all these three variables show significant differences in the means of $\mathrm{L}$ and $\mathrm{H}$ and in the median of $\mathrm{H} / \mathrm{L}$, there is considerable overlap between the measurements in two populations (Table 1). The carapace size of juveniles follows logically the same pattern as that of the adult females - larger juveniles were recorded in $\mathrm{GH}$ and smaller in AR (Table 1).

A1. The AR females are characterised by a relatively shorter $\mathrm{V}$ podomere and slightly more elongated (the larger L/W ratio) podomeres IV, VI and VII than those in the GH females. Although there are statistically significant differences between the medians of these 
ratios (Table 2), the antennules of the females from both populations still exhibit a scheme typical for $C$. vavrai, i.e. a sub-quadrate IV podomere and relatively short and wide podomeres V and VI (significantly shorter than IV podomere).

A2. The major difference refers to the relative $\mathrm{L}$ of both apical claws on the EIV $\left(\mathrm{G}_{\mathrm{M}}\right.$ and $\left.\mathrm{G}_{\mathrm{m}}\right)$ and of the aesthetascs $\mathrm{Y}$, which are significantly larger in the AR females as compared with those of the $\mathrm{GH}$ females (Table 3$)$. Similarly, the other claws $\left(\mathrm{G}_{1}, \mathrm{G}_{2}, \mathrm{G}_{3}\right.$ and $\mathrm{z}_{1}$ ) are also larger in the AR females and indeed statistical comparison shows significant differences between the medians of the relative $\mathrm{L}$ of these claws for both populations too. However, considerable overlaps are apparent in these cases (Table 3). It could well be that the recorded morphological differences are influenced by the environment as the AR females were collected from ground waters while the $\mathrm{GH}$ females from surface waters. Elongation and hyper-development of some claws, setae (especially aesthetascs) and/or limb podomeres is one of the morphological criteria on which to define stygobiont ostracods (e.g. Danielopol \& Hartmann 1986).

L6. The AR females possess distinctly larger distal claw $\left(\mathrm{h}_{2}\right)$ than that of the GH females (Table 4 ), hence the same pattern of variability as observed in the second antenna may be seen.

Fu. The compared females differ also in the relative $\mathrm{L}$ of both furcal claws, which are again larger in the AR females than those in the GH females (Table 4).

To sum up, the most important differences between the females from Arcine and Gummer's How refer to the elongation of the antennal claws $G_{M}$ and $G_{m}$, the distal claw h2 on the walking leg and the antennal aesthetasc $\mathrm{Y}$ in the females from the former population. Nonetheless, all the differences between the females from these two populations express the intraspecific variability of the species and are not taxonomically significant. Future studies based on larger number of populations and devoted to the inter- and intrapopulational variation of this species should be undertaken in order to trace its microevolutionary pathways, to identify these changes that could caused speciation and eventually to verify if some of the isolated populations (e.g. that one from SM with the fairly peculiar male) deserve separate (sub-)specific status.

Comments on the position of $C$. vavrai in the genus Cryptocandona and on the occurrence of $C$. vavrai males

Within the genus, C. vavrai with its unique characters (broad inner lamella of the valves, A1 with 3rd ramus podomere lacking posterior seta, L7 with hook-li- ke seta $\mathrm{h}_{1}$ ) does not show clear similarity with any other species except for Cryptocandona longipes (Ekman), originally described from females (one with spermatozoa in seminal receptacle) collected from two peatbogs in the environs of Torne Träsk in N Sweden (Ekman 1908). The types of the latter species are considered to be lost; the only other record was made by Särkkä et al. (1997), based on Finnish material, but these specimens are also no longer available (J. Särkkä pers. comm. to T.N.). Relying on the original description by Ekman (1908), C. longipes differs from $C$. vavrai mainly in a) the more elongated carapace in lateral view, b) larger size (1.03-1.08 $\mathrm{mm}$ ) and c) divided EII and EIII of the cleaning leg. These characters seem to express the variability of one species and hence the name $C$. longipes is here considered a possible subjective synonym of $C$. vavrai. Nevertheless, specimens from northern Scandinavia could still deserve a separate taxonomic status at a subspecific rank, but this needs further investigations.

Cryptocandona vavrai seems to take an intermediate position in the genus, displaying slightly closer phylogenetic affinities with a group of typical stygobitic species (C. dudichi (Klie), C. kieferi (Klie), C. leruthi (Klie), C. matris (Sywula), C. phreaticola (Kiefer et Klie)) rather than with most probably more primitive representatives of the genus $(C$. brehmi (Klie) and $C$. reducta (Alm)). With the former group of species $C$. vavrai shares the similar morphology of A1 (the relatively long terminal podomere and long setae on the penultimate podomere) and of furca (distinctly unequal $\mathrm{G}_{\mathrm{a}}$ and $\mathrm{G}_{\mathrm{p}}$ ), as was already documented by Namiotko \& Danielopol (2002). Nevertheless, the clear differences of $C$. vavrai from other species (see the diagnosis above) suggest that it could represent a distinct evolutionary lineage within Cryptocandona. Two other species of Cryptocandona, i.e. C. angustissima (Ekman) and C. pygmaea (Ekman), are not considered here since they are still very poorly known and need to be redescribed.

Cryptocandona vavrai is a good example of species represented by parthenogenetic populations with rare males scattered throughout Europe without any recognisable pattern. Such a random distribution of males is characteristic for most fresh water species in the family Candonidae with presumably mixed reproduction, while the "classic" geographical parthenogenesis can be found only exceptionally in this family (Horne et al. 1998). In the genus Cryptocandona bisexual reproduction seems to prevail. Males have never been found for three species: C. angustissima and C. brehmi (for which only single female specimens are thus far known at all), and C. pygmaea, whereas sporadic oc- 
currences of males have been reported for $C$. reducta and $C$. vavrai. Males of the remaining Cryptocandona species seem to be always present. Therefore, one can hypothesise that $C$. vavrai has arisen from interspecific hybridization. However, as the functionality of single males in Candonidae has so far not been shown and their origin and role in this lineage remain almost unknown, the hybridisation-based scenario to explain the origin of $C$. vavrai is highly speculative at the moment, but worthy of further investigation.

\section{Distribution}

Cryptocandona vavrai is the most common species of the genus, broadly distributed throughout the European continent except for the southern- and easternmost areas. For reviews of the distribution of the species see Löffler \& Danielopol (1978) and Meisch (2000). The distribution map (Fig. 1) is based on the NODE database with supplementary data on the first records for Finland by Särkkä et al. (1997) and for Hungary by Gidó \& Lakatos (2001), as well as more recent findings from the Harz Mountains in Germany (Scharf et al. 2004), southern and northern Sweden (Heider \& Scharf 1999, Iglikowska \& Namiotko 2004, respectively), environs of Valencia in Spain (Mezquita et al. 2001) and from Belgium, SE and E France, N Italy, SE Poland and Romania (Baltanás et al. 2000). Altinsaçli's (1997) record in NW Turkey is erroneous (see discussion above). The species is thought now to be absent only from Portugal, southern and central Spain, peninsular Italy, the Balkan (Albania, Bulgaria, Greece and the former SFR of Yugoslavia) and east of the border of the former USSR except for two lakes in the region of Russian Karelia (Akatova \& Järvekülg
1965). With respect to its occurrence in Karelia and Poland, the fact that this species has not been reported yet from Estonia, Latvia, Lithuania and Belorussia is believed to be a result of inadequate sampling rather than ecological constraints. So far, the species is also unknown in the Netherlands and Denmark but it most probably occurs there. Further and more extensive sampling would most certainly show $C$. vavrai to be present almost everywhere in Europe in suitable habitats north of latitude $40-45^{\circ} \mathrm{N}$. Although one can be far less certain when extrapolating the eastern limit of the distribution area of this species, it seems that $C$. vavrai is more common in NE and E Europe than the few records would indicate. In the Polish Carpathians however the species is gradually replaced by Cryptocandona matris in the transect from the west to east along the northern slopes of the mountain ranges (Sywula 1981).

Cryptocandona vavrai is the sole extant representative of the genus having fossil records. Valves assigned to this species were recorded in Quaternary (Mid and Late Pleistocene, Holocene) sediments from: Belgium, Czech Republic, Germany, Great Britain, Hungary, Ireland, Poland and Slovakia (references in Griffiths 1995).

\section{Ecology}

Cryptocandona vavrai is generally considered a genuine spring-dweller, most frequently reported from cold helocrene marshlands. Furthermore, it successfully colonises and most certainly is able to disperse in subsurface waters, occurring in both the shallow hyporheal of running waters and in deep porous groundwaters of alluvial valleys (Baltanás et al. 2000, Meisch 2000). In spite of its common habitats, C. vavrai has

Table 5. Summary of the ranges of various physical and chemical water properties for sites hosting Cryptocandona vavrai (source references given in the text).

\begin{tabular}{|c|c|c|}
\hline Variable (unit) & Range & Most records \\
\hline water temperature $\left({ }^{\circ} \mathrm{C}\right)$ & $3.0-13.5$ & $8-10$ \\
\hline $\mathrm{pH}$ & $4.6-8.8$ & $5.5-7.0$ \\
\hline conductivity $\left(\mu \mathrm{S} \mathrm{cm}{ }^{-1}\right)$ & $60-1250$ & $60-100$ and $700-1250$ \\
\hline dissolved oxygen concentration ( $\mathrm{mg} \mathrm{O}_{2} \mathrm{dm}^{-3}$ ) & $1.5-10.2$ & approx. $6-9$ \\
\hline alkalinity (meq $\mathrm{dm}^{-3}$ ) & approx. 0.2-0.4 & \\
\hline total cations (meq $\mathrm{dm}^{-3}$ ) & $0.55-0.61^{*}$ & \\
\hline total anions (meq $\mathrm{dm}^{-3}$ ) & $0.55-0.61^{*}$ & \\
\hline chloride concentration ( $\mathrm{mg} \mathrm{Cl} \mathrm{dm}^{-3}$ ) & $6.7-15.6$ & \\
\hline nitrate concentrations ( $\mathrm{mg} \mathrm{NO}{ }_{3}^{-} \mathrm{dm}^{-3}$ ) & $0.9^{* *}$ & \\
\hline phosphate concentrations ( $\mathrm{mg} \mathrm{PO}_{4}{ }^{-3} \mathrm{dm}^{-3}$ ) & $0.1^{* *}$ & \\
\hline water discharge $\left(\mathrm{dm}^{3} \mathrm{~s}^{-1}\right)$ & $0.1-2.0$ & $0.4-0.6$ \\
\hline
\end{tabular}

\footnotetext{
* range of the mean values ** single measurement
} 
been collected from trickling streams with irregular water level and shallow ditches (Klie 1938), temporary and permanent pools (Nüchterlein 1969) and from both shallower and deeper (maximum depth $8 \mathrm{~m}$ ) bottom of ponds and lakes (Akatova \& Järvekülg 1965, Fox 1966, Scharf 1980, Horne 1988), where its presence may well be due to sub-aqueous springs.

Compiling data of Husmann (1956), Wegelin (1966), Nüchterlein (1969), McCall (1975), Ronneberger (1975), Scharf (1982), Horne (1988), Roca \& Baltanás (1993), Särkkä et al. (1997), Heider \& Scharf (1999), Mezquita et al. (2001), Scharf et al. (2002) and our own (unpubl.), the ranges of various physical and chemical water properties for sites hosting C. vavrai are given in Table 5.

Nüchterlein (1969) assumed C. vavrai to be oligothermophilic, rheoeuryplastic (tolerant of a water flow) and titanoeuryplastic (tolerant of a wide range of calcium content).

Cryptocandona vavrai is probably a bivoltine species producing its generations in spring and autumn, although adults occur throughout a year (Sywula 1974). Only one record of the estimated population

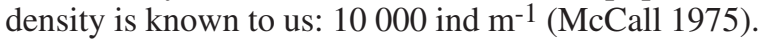

In conclusion, most records of the natural history of C. vavrai show it to be a crenobiontic stygophile having a clear preference for rather cool, slightly acidic and well-oxygenated waters. However, as the species was captured also from a marshy system associated with a thermal spring in SE France (site no 9 in Baltanás et al. 2000), it is likely that temperature tolerance varies among clones, and in spite of the fact that most populations are limited to cold waters, some could be more eurythermal, as was already stated by Baltanás et al. (2000). Furthermore, as other aspects of ecological tolerances in $C$. vavrai are much less known, it may well be that other constraints (e.g. biomechanical, nutritional) are here of importance too.

\section{Acknowledgements}

We benefited from scientific exchange programmes between the Austrian Academy of Sciences (D.L.D.), the Polish Academy of Sciences (T.N.) and the Royal Society (D.J.H.). Jerzy Bohdanowicz and Robert Szymanczak are acknowledged for technical assistance with the illustrations. This work was also partly supported by EU Marie Curie RT Network SexAsex (contract MRTN-CT-2004512492).

\section{References}

Akatova N.A. \& Järvekülg A.A. 1965. - Rakushovye rakoobraznye ozer Karelii. Pages 147-152 in Fauna ozer Karelii. Bespozvonochye. Nauka, Moskva-Leningrad.

Altinsaçli S. 1997. - The Ostracoda (Crustacea) fauna of Lake Sapanca. Istanbul Univ., J. Biol., 60, 17-45.

Baltanás A., Namiotko T. \& Danielopol D.L. 2000. - Biogeography and disparity within the genus Cryptocandona (Crustacea, Ostracoda). Vie Milieu, 50, 297-310.

Broodbakker N.W. \& Danielopol D.L. 1982. - The chaetotaxy of Cypridacea (Crustacea, Ostracoda) limbs: proposals for a descriptive model. Bijdr. Dierk., 52, 103-120.

Danielopol D.L. 1969. - Recherches sur la morphologie de l'organe copulateur mâle chez quelques ostracodes du genre Candona Baird (Fam. Cyprididae Baird). Pages 136-153 in The taxonomy, morphology and ecology of Recent Ostracoda. Neale J.W. (ed.). Oliver \& Boyd, Edinburgh.

Danielopol D.L. 1978. - Über Herkunft und Morphologie der Süßwasser-hypogäischen Candoninae (Crustacea, Ostracoda). Sitzungsber. Österreichischer Akad. Wiss. (Mathem.-naturw. Kl.), 187, 1-162.

Danielopol D.L. \& Hartmann G. 1986. - Ostracoda. Pages 265-294 in Stygofauna Mundi. A faunistic, distributional, and ecological synthesis of the World fauna inhabiting subterranean waters (including the marine interstitial). Botosaneanu L. (ed.). E.J. Brill/Dr. W. Backhuys, Leiden.

Eichhorn A. 1968. - Cryptocandona vavrai, Kaufm. et Scottia browniana, Jones, deux rares Ostracodes (Crustacea) du Grand-Duché de Luxembourg. Archs Inst. gr.-d. Luxemb. (sect. sci. nat., phys. math.) (n.s.), 33, 211-223.

Ekman S. 1908. - Ostracoden aus den nordschwedischen Hochgebirgen. Naturw. Unters. d. sarekgeb., 4, 169-198.

Fox H.M. 1966. - Ostracods from the environs of Pallanza. Mem. Ist. Ital. Idrobiol., 20, 25-39.

Gidó Z. \& Lakatos G. 2001. - Faunisztikai eredmények forrásaink Ostracodáiról. Hidrol. Közl., 81, 367-368.

Griffiths H.I. 1995. - European Quaternary freshwater Ostracoda : a biostratigraphic and palaeobiogeographic primer. Scopolia, 34, 1168.

Heider V. \& Scharf B. 1999. - Musselkräftor i Mellanblekinges sjöar. Särtryck ur Blekinges Natur, 1999, 92-107.

Horne D.J. 1988. - Recent freshwater Ostracoda of the Lake District. British Micropalaeontological Society Field Guide No. 7. University College of Wales, Aberystwyth, 28 p.

Horne D.J., Baltanás A. \& Paris G. 1998. - Geographical distribution of reproductive modes in living non-marine ostracods. Pages $77-$ 99 in Sex and parthenogenesis: evolutionary ecology of reproductive modes in non-marine ostracods. Martens K. (ed.). Backhuys, Leiden.

Husmann S. 1956. - Untersuchungen über die Grundwasserfauna zwischen Harz und Weser. Arch. Hydrobiol., 52, 1-184.

Iglikowska A. \& Namiotko T. 2004. - Przyczynek do znajomości Ostracoda szwedzkiej Laponii. Pages 56-58 in Bioróznorodność środowisk dna zbiornikow wodnych. Namiotko T. \& Sywula T. (eds). BEL Studio, Gdańsk-Warszawa.

Kaufmann A. 1900a. - Neue Ostracoden aus der Schweiz. Zool. Anz., 23, 131-133.

Kaufmann A. 1900b. - Cypriden und Darwinuliden der Schweiz. Rev. Suisse Zool., 8, 209-423.

Klie W. 1938. - Ostracoda, Muschelkrebse. Die Tierwelt Deutschlands und der angrenzenden Meeresteile nach ihren Merkmalen und nach ihrer Lebensweise. Gustav Fischer Verl., Jena, 230 $\mathrm{p}$

Löffler H.H. \& Danielopol D. 1978. - Ostracoda (Cyprididae). Pages 196-208 in Limnofauna Europaea. Illies J. (ed.) Gustav Fischer Verl., Stuttgart.

Mallard F., Reygrobellet J.L., Laurent R. \& Mathieu J. 1997. - Developments in sampling the fauna of deep water-table aquifers. Arch. Hydrobiol., 138, 401-432.

Martens K. 1987. - Homology and functional morphology of the sexual dimorphism in the antenna of Sclerocypris Sars, 1924 (Crustacea, Ostracoda, Megalocypridinae). Bijdr. Dierk., 57, 183190. 
McCall G. 1975. - The ostracods Candona vavrai and Candona reducta in Ireland. Irish Nat. J., 18, 223-224.

Meisch C. 1996. - Contribution to the taxonomy of Pseudocandona and four related genera, with the description of Schellencandona nov. gen., a list of the Candoninae genera, and a key to the European genera of the subfamily (Crustacea, Ostracoda). Bull. Soc. Nat. luxemb., 97, 211-237.

Meisch C. 2000. - Freshwater Ostracoda of western and central Europe. Spektrum Akad. Verl., Heidelberg-Berlin, $522 \mathrm{p}$.

Mezquita F., Griffiths H.I., Domínguez M.I. \& Lozano-Quilis M.A. 2001. - Ostracoda (Crustacea) as ecological indicators: a case study from Iberian Mediterranean brooks. Arch. Hydrobiol., 150, 545-560.

Namiotko T. \& Danielopol D.L. 2001. - Redescription of two rare hypogean species of the genus Cryptocandona Kaufmann (Ostracoda). Crustaceana, 74, 557-580.

Namiotko T. \& Danielopol D.L. 2002. - Morphology and phylogenetic affinities of Cryptocandona brehmi (Klie, 1934) (Ostracoda Podocopida). Crustaceana, 74, 1349-1363.

Namiotko T., Marmonier P. \& Danielopol D.L. 2005. - Cryptocandona kieferi (Crustacea, Ostracoda): redescription, morphological variability, geographical distribution. Vie Milieu, 55 : 91-108.

Namiotko T., Meisch C., Gidó Z. \& Danielopol D.L. 2001. - Redescription, taxonomy, distribution and ecology of Cryptocandona dudichi (Klie, 1939) (Crustacea, Ostracoda). Bull. Soc. Nat luxemb., 102, 109-130.

Nüchterlein H. 1969. - Süsswasserostracoden aus Franken. Ein Beitrag zur Systematik und Ökologie der Ostracoden. Int. Revue ges. Hydrobiol., 54, 223-287.

Roca J.R. \& Baltanás A. 1993. - Ecology and distribution of Ostracoda in Pyrenean springs. J. Crust. Biol., 13, 165-174.

Ronneberger D. 1975. - Zur Kenntnis der Grundwasserfauna des Saale-Einzugsgebietes (Thüringen). Limnologica, 9, 323-419.

Särkkä J., Levonen L. \& Mäkelä J. 1997. - Meiofauna of springs in Finland in relation to environmental factors. Hydrobiologia, 347, 139-150.

Scharf B.W. 1980. - Zur rezenten Muschelkrebsfauna der Eifelmaare (Crustacea: Ostracoda). Mitt. Pollichia, 68, 185-204.

Scharf B.W. 1982. - Muschelkrebse aus dem Murnauer Moos (Crustacea, Ostracoda). Entomofauna, Suppl.1, 119-123.

Scharf B.W., Heitkamp U., Hartmann G. \& Müller A. 2004. - Zur Ostracodenfauna des Harzes und seiner Vorländer. Mitt. Naturw. Ver. Goslar, 7, 195-218.

Sywula T. 1974. - Małżoraczki Ostracoda. Fauna Słodkowodna Polski, 24. Państwowe Wydawnictwo Naukowe, Warszawa-Poznań, 315 p.

Sywula T. 1981. - Małżoraczki (Ostracoda) wód podziemnych Polski. Roczn. Muz. Okreg. Czestochowa, Przyroda, 2, 89-96.

Wegelin R. 1966. - Beitrag zur Kenntnis der Grundwasserfauna des Saale-Elbe-Einzugsgebietes. Zool. Jb. Syst., 93, 1-117. 